\title{
Pasting Properties of Quality Protein Maize and Teff Composite Flours
}

\author{
Umer Asrat Yasin \\ Food Science and Nutrition Research Directorate, Pawe Agricultural Research Center, Ethiopian Institute of Agricultural Research, Pawe, \\ Ethiopia
}

\author{
Email address: \\ umerasrat88@gmail.com
}

To cite this article:

Umer Asrat Yasin. Pasting Properties of Quality Protein Maize and Teff Composite Flours. International Journal of Food Engineering and Technology. Vol. 5, No. 1, 2021, pp. 1-7. doi: 10.11648/j.ijfet.20210501.12

Received: January 22, 2021; Accepted: March 17, 2021; Published: March 30, 2021

\begin{abstract}
Quality protein maize (QPM) is a type of biofortified maize, and contains lysine and tryptophan which are the essential amino acids for growth and development. Increasing the consumption of food products prepared from quality protein maize is the ideal solution to tackle protein deficiency related problems. Teff is a staple food crops in Ethiopia. It is gluten free cereal grains, and has great potential to be formulated into a range of food and beverage products. Flour pasting properties are one of the most important quality parameter and its affects texture, digestibility, and end use of the food products. The study was aimed to evaluate the effect of blending ratio and varieties on pasting properties of QPM-teff composite flours. Quality protein maize flours from two varieties were blended with teff flour at the ratio of 70:30, 60:40, and 100\% (QPM) was taken as a control sample. Peak viscosity, trough viscosity, breakdown viscosity, final viscosity, setback viscosity, and pasting time of the composite flour samples ranged from 520.50 to $1068.50 \mathrm{cP}, 491.50$ to $802.00 \mathrm{cP}, 29.00$ to $266.50 \mathrm{cP}, 1232.00$ to 2358.50 $\mathrm{cP}, 740.50$ to $1556.50 \mathrm{cP}$, and 5.04 to 5.70 mins due to blending ratio, and from 598.17 to $956.00 \mathrm{cP}, 519.83$ to $774.83 \mathrm{cP}$, 78.33 to $181.17 \mathrm{cP}, 1391.67$ to $2297.00 \mathrm{cP}, 871.83$ to $1522.17 \mathrm{cP}$, and 5.15 to 5.28 mins due to varieties, respectively.
\end{abstract}

Keywords: Quality Protein Maize, Teff, Composite Flour, Pasting Properties

\section{Introduction}

Quality protein maize (QPM) can be used as a replacement of conventional maize in communities where maize is used as a source of protein [30], and have the potential to reduce the protein and essential amino acid inadequacy gaps in most developing cereal dependent countries $[15,27]$. It contains nearly twice the quantity of lysine $(>4.0 \%)$ and tryptophan $(>0.8 \%)$ present in the conventional maize $[11,13]$. The higher lysine and tryptophan contents of quality protein maize varieties compared to the conventional maize provide a more balanced protein for humans and other monogastric animals [1]. Quality protein maize also contains higher amounts of histidine, arginine, aspartic acid and glycine, and reduced levels of glutamic acid, alanine and leucine [22]. The lower levels of leucine are an added advantage as it results in a more balance leucine-isoleucine ratio that helps to liberate more tryptophan [18].

Quality protein maize varieties have higher biological value than the common maize types. The biological value of QPM is about $80 \%$ whereas that of conventional maize is $45 \%$. This means that in conventional maize a protein intake of only $37 \%$ is being utilized when compared to $74 \%$ of the same amount in QPM [12]. Quality protein maize varieties are particularly impactful in rural areas with limited access to dietary supplements and fortified foods. Therefore, the conversion of conventional maize into QPM significantly improves its nutritional value for humans and animals $[22,7]$.

Teff is a cereal crop and its use as human food is mostly confined to its origin, Ethiopia [6]. It is mainly used to make a traditional fermented-circular soft bread called injera or flat bread [23]. Teff can also be used to prepare porridge, kitta (unleavened breads), atmit (gruel) and traditional alcoholic beverages like tella (opaque beer), arake and shameta. In recent years, teff is gaining popularity around the world mostly due to its attractive nutritional properties. It is gluten free and has great potential to be formulated into a range of food and beverage products to aid people with celiac disease [14].

Pasting properties of flour is one of the most important properties influencing the quality and aesthetic consideration 
of food that affects the texture, digestibility and end use of starch-based food commodities. It includes peak viscosity, trough viscosity, setback viscosity, breakdown viscosity, final viscosity, peak time and pasting temperature $[4,16,33]$. The use of composite flours in preparation of starchy meals often alter their compositions, and may therefore change the functional and pasting characteristics of the final product [3]. The objective of the study was to determine the pasting properties of flours from two quality protein maize varieties blended with teff flour. Both QPM and teff varieties were released by Ethiopian Institute of Agricultural Research.

\section{Materials and Methods}

\subsection{Sample Preparation}

Quality protein maize varieties, Melkassa-1Q (color: yellow and texture: flint) and Melkassa-6Q (color: white and texture: semi-flint) were collected from Melkassa Agricultural Research Center and teff variety Magna (DZ-01196) was obtained from Debre Zeit Agricultural Research Center, Ethiopian Institute of Agricultural Research. The QPM grains were winnowed and pounded to remove the husk (tip-cap) and the teff grains were cleaned through sieving. Then, separately milled to a sieve size of $0.50 \mathrm{~mm}$ (ASTM, Model-E11, USA) using cyclone miller (UDY3010019, USA). Flour from two QPM varieties was blended with $30 \%$ and $40 \%$ teff flour, respectively [25].

\subsection{Determination of Flour Pasting Properties}

The pasting properties of flour samples were determined using Rapid Visco-Analyzer (Model 3C, Newport Scientific, Sydney, NSW, Australia). About $3.50 \mathrm{~g}$ of flour sample (14\% moisture basis) was dispersed in $25 \mathrm{ml}$ distilled water. Then, the analysis was carried out at a programmed heating and cooling cycle where the samples held at $50^{\circ} \mathrm{C}$ for $1 \mathrm{~min}$, heated at $95^{\circ} \mathrm{C}$ for $3.8 \mathrm{mins}$ and held at $50^{\circ} \mathrm{C}$ for $1.4 \mathrm{mins}$ and the pasting performance of the flour samples; the peak viscosity (PV), trough viscosity (TV), breakdown viscosity (BV), final viscosity (FV), setback viscosity (SBV), and pasting time $(\mathrm{Pt})$ were calculated from the pasting curve using Thermocline for Windows Software Newport [8, 31].

\subsection{Experimental Design and Analysis}

The pasting properties of the flour samples were studied using Complete Randomized Design (CRD) and factorial design in CRD arrangement. The experimental data was statistically analyzed using SAS software (version 9.4) following PROC ANOVA procedures. The results were expressed as mean \pm standard deviation. Statistical differences between the means $(p<0.05)$ were tested by Fischer's least significant differences (LSD).

\section{Results and Discussions}

\subsection{Pasting Properties of Quality Protein Maize and Teff Flours}

The pasting properties of quality protein maize and teff flours are listed in Table 1 and significant differences $(p<0.05)$ were observed between the results. The peak viscosity (PV), trough viscosity (TV), breakdown viscosity (BV), final viscosity $(\mathrm{FV})$, setback viscosity $(\mathrm{SBV})$, and pasting time $(\mathrm{Pt})$ of the samples ranged from $520.50-1721.50 \mathrm{cP}, 491.50-$ $969.50 \mathrm{cP}, 29.00-752.00 \mathrm{cP}, 1232.00-2808.50 \mathrm{cP}, 740.50-$ $1839.00 \mathrm{cP}$, and $5.20-5.70 \mathrm{mins}$, respectively. Results recorded for pasting properties of QPM flour was lower than the values reported by Sangeeta and Grewal (2018) [20]: PV $(1389-1409 \mathrm{cP})$, TV $(1263-1275 \mathrm{cP}), \mathrm{BV}(126-134 \mathrm{cP})$, FV (3847 - $3869 \mathrm{cP})$, and SBV (2584 - $2593 \mathrm{cP})$ but in agreement with Pt (5.73 - 5.82 mins) results. Sagbo et al. (2017) [19] also reported that the pasting properties of QPM flour; PV (823.5 to $992.50 \mathrm{cP}$ ), TV (820.0 to $916.50 \mathrm{cP})$, BV (3.50 to $76.0 \mathrm{cP}), \mathrm{FV}$ (2016.50 to $3048.0 \mathrm{cP}), \mathrm{SBV}$ (1196. 50 to $2131.50 \mathrm{cP}$ ), and $\mathrm{Pt}$ (5.40 to $6.90 \mathrm{mins}$ ).

Pasting properties result recorded for teff flour was in line with the findings reported by Workineh and Ronda (2014) [26]: PV (1304.0 - $1676.0 \mathrm{cP})$, TV (744.0 - 883.0 cP), BV $(478.0-853.0 \mathrm{cP})$, and higher than FV $(1690.0-1957.0 \mathrm{cP})$ and SBV $(861.0-1113.0 \mathrm{cP})$ values. Pasting time $(8.33-8.73$ mins) also found slightly higher than the values obtained in this study. Teshome (2017) [24] also reported pasting properties of teff flour in some ranges: PV (759.5 to 1434.5 cP), TV (736.5 to $947.5 \mathrm{cP}), \mathrm{BV}$ (23 to $487 \mathrm{cP}$ ), FV (1490.5 to $1897.5 \mathrm{cP}), \mathrm{SBV}$ (754.5 to $950 \mathrm{cP})$, and $\mathrm{Pt}$ (5.13 to $5.53 \mathrm{mins})$.

Table 1. Pasting properties of QPM and teff flours.

\begin{tabular}{|c|c|c|c|c|c|c|}
\hline Flours & PV (cP) & TV (cP) & BV (cP) & FV (cP) & SBV (cP) & Pt (mins) \\
\hline Melkassa-1Q & $844.50 \pm 34.65^{b}$ & $749.50 \pm 27.58^{b}$ & $95.00 \pm 7.07^{b}$ & $2204.50 \pm 166.17^{b}$ & $1455.00 \pm 138.59^{b}$ & $5.20 \pm 0.18^{b}$ \\
\hline Melkassa-6Q & $520.50 \pm 20.51^{\mathrm{c}}$ & $491.50 \pm 16.26^{\mathrm{c}}$ & $29.00 \pm 4.24^{\mathrm{b}}$ & $1232.00 \pm 39.60^{\mathrm{c}}$ & $740.50 \pm 23.33^{\mathrm{c}}$ & $5.70 \pm 0.04^{\mathrm{a}}$ \\
\hline CV (\%) & 0.73 & 1.44 & 2.29 & 3.87 & 5.26 & 1.45 \\
\hline LSD & 32.20 & 45.67 & 28.76 & 347.06 & 304.38 & 0.34 \\
\hline
\end{tabular}

Data: mean $\pm \mathrm{SD}$, means with the same letter in the column are not significantly different $(\mathrm{p}<0.05)$, $\mathrm{PV}=\mathrm{Peak}$ Viscosity, $\mathrm{TV}=\mathrm{Trough}$ Viscosity, $\mathrm{BV}=$ Breakdown Viscosity, $\mathrm{FV}=$ Final Viscosity, $\mathrm{SBV}=$ Setback Viscosity, $\mathrm{Pt}=$ Pasting time, and centipoise $(\mathrm{cP})$.

\subsection{Pasting Properties of Quality Protein Maize and Teff Composite Flours}

The pasting properties of QPM-teff composite flour are summarized in Table 2. The peak viscosity values ranged between 520.50 to $1068.50 \mathrm{cP}$, and significant variations $(p<0.05)$ were observed due to blending ratio and varieties. 
The highest value was recorded for composite flour of Melkassa-1Q (60\%) and teff (40\%), and the lowest value was recorded for Melkassa-6Q (100\%) flour. Peak viscosity is the highest viscosity attained during heating at $95^{\circ} \mathrm{C}$ and it has been reported to be closely associated with the degree of starch damage and high starch damage results in high peak viscosity [21,32]. Damaged starch may negatively impact on the quality of food products $[5,29]$.

Trough viscosity sometimes referred to as shear thinning, holding strength or hot paste viscosity is a period when the samples were subjected to a period of constant temperature and mechanical shear stress [10]. Trough viscosity results of QPM-teff composite flour samples ranged between $491.50-$
$802.00 \mathrm{cP}$. The highest value was recorded for QPM-teff composite flour ratio of 60:40 (Melkassa-1Q: teff) and the lowest value was recorded Melkassa-6Q (100\%) flour.

Breakdown viscosity is the difference between peak and tough viscosity, and it is an indication of the rate of gelling stability which is dependent on the nature of the product [2, 28]. The breakdown viscosity of the flour samples were significantly influenced $(\mathrm{p}<0.05)$ by blending ratio and varieties. The highest value was recorded for 60:40 (Melkassa-1Q: teff) blends and the lowest value was recorded for Melkassa-6Q (100\%) flour. As teff flour increased in the composite increment in breakdown viscosity values were observed.

Table 2. Effect of blending ratio and varieties on pasting properties of QPM-teff composite flour.

\begin{tabular}{|c|c|c|c|c|c|c|}
\hline Blending ratio (\%) & PV (cP) & TV (cP) & $\mathrm{BV}(\mathbf{c P})$ & FV (cP) & SBV (cP) & Pt (mins) \\
\hline $\mathrm{B} 1$ & $844.50 \pm 34.65^{\mathrm{c}}$ & $749.50 \pm 27.58^{b}$ & $95.00 \pm 7.07^{\mathrm{d}}$ & $2204.50 \pm 166.17^{\mathrm{a}}$ & $1455.00 \pm 138.59^{\mathrm{a}}$ & $5.20 \pm 0.18^{\mathrm{b}}$ \\
\hline B2 & $955.00 \pm 11.01^{\mathrm{b}}$ & $773.00 \pm 12.00^{\mathrm{b}}$ & $182.00 \pm 2.10^{\mathrm{b}}$ & $2328.00 \pm 45.25^{\mathrm{a}}$ & $1555.00 \pm 45.25^{\mathrm{a}}$ & $5.07 \pm 0.00^{\mathrm{b}}$ \\
\hline B3 & $1068.50 \pm 12.02^{\mathrm{a}}$ & $802.00 \pm 4.24^{\mathrm{a}}$ & $266.50 \pm 7.78^{\mathrm{a}}$ & $2358.50 \pm 26.16^{\mathrm{a}}$ & $1556.50 \pm 21.92^{\mathrm{a}}$ & $5.17 \pm 0.05^{b}$ \\
\hline B4 & $520.50 \pm 20.51^{\mathrm{f}}$ & $491.50 \pm 16.26^{\mathrm{d}}$ & $29.00 \pm 4.24^{\mathrm{f}}$ & $1232.00 \pm 39.60^{\mathrm{c}}$ & $740.50 \pm 23.33^{\mathrm{c}}$ & $5.70 \pm 0.04^{\mathrm{a}}$ \\
\hline B5 & $603.00 \pm 26.87^{\mathrm{e}}$ & $533.00 \pm 22.63^{\mathrm{c}}$ & $70.00 \pm 4.23^{\mathrm{e}}$ & $1415.50 \pm 19.09^{\mathrm{b}}$ & $882.50 \pm 3.54^{\mathrm{bc}}$ & $5.04 \pm 0.05^{\mathrm{b}}$ \\
\hline B6 & $671.00 \pm 21.21^{\mathrm{d}}$ & $535.00 \pm 5.66^{\mathrm{c}}$ & $136.00 \pm 15.56^{\mathrm{c}}$ & $1527.50 \pm 48.79^{b}$ & $992.50 \pm 43.13^{\mathrm{b}}$ & $5.10 \pm 0.04^{b}$ \\
\hline CV (\%) & 1.55 & 1.71 & 4.03 & 3.75 & 5.13 & 1.49 \\
\hline LSD & 30.92 & 28.51 & 13.43 & 177.57 & 157.88 & 0.20 \\
\hline Variety & PV (cP) & TV (cP) & BV (cP) & FV (cP) & SBV (cP) & Pt (mins) \\
\hline Melkassa-1Q & $956.00 \pm 12.01^{\mathrm{a}}$ & $774.83 \pm 2.79^{\mathrm{a}}$ & $181.17 \pm 2.81^{\mathrm{a}}$ & $2297.00 \pm 4.17^{\mathrm{a}}$ & $1522.17 \pm 3.39^{\mathrm{a}}$ & $5.28 \pm 0.04^{\mathrm{a}}$ \\
\hline Melkassa-6Q & $598.17 \pm 10.44^{\mathrm{b}}$ & $519.83 \pm 2.71^{\mathrm{b}}$ & $78.33 \pm 1.43^{\mathrm{b}}$ & $1391.67 \pm 1.77^{\mathrm{b}}$ & $871.83 \pm 2.24^{\mathrm{b}}$ & $5.15 \pm 0.03^{b}$ \\
\hline CV (\%) & 1.55 & 1.71 & 4.03 & 3.75 & 5.13 & 1.49 \\
\hline LSD & 17.85 & 16.46 & 7.75 & 102.52 & 91.16 & 0.12 \\
\hline
\end{tabular}

Data: mean $\pm \mathrm{SD}$, means with the same letter in the column are not significantly different $(\mathrm{p}>0.05), \mathrm{PV}=$ Peak Viscosity, TV=Trough Viscosity, $\mathrm{BV}=$ Breakdown Viscosity, FV=Final Viscosity, $\mathrm{SBV}=$ Setback Viscosity, Pt=Pasting time, and centipoise (cP).

Melkassa-1Q (B1 $=100 \%$ QPM, B2 $=70 \%$ QPM $+30 \%$ Teff, B3 $=60 \%$ QPM $+40 \%$ Teff $)$

Melkassa-6Q (B4=100\% QPM, B5= 70\% QPM $+30 \%$ Teff, B6 $=60 \%$ QPM $+40 \%$ Teff)

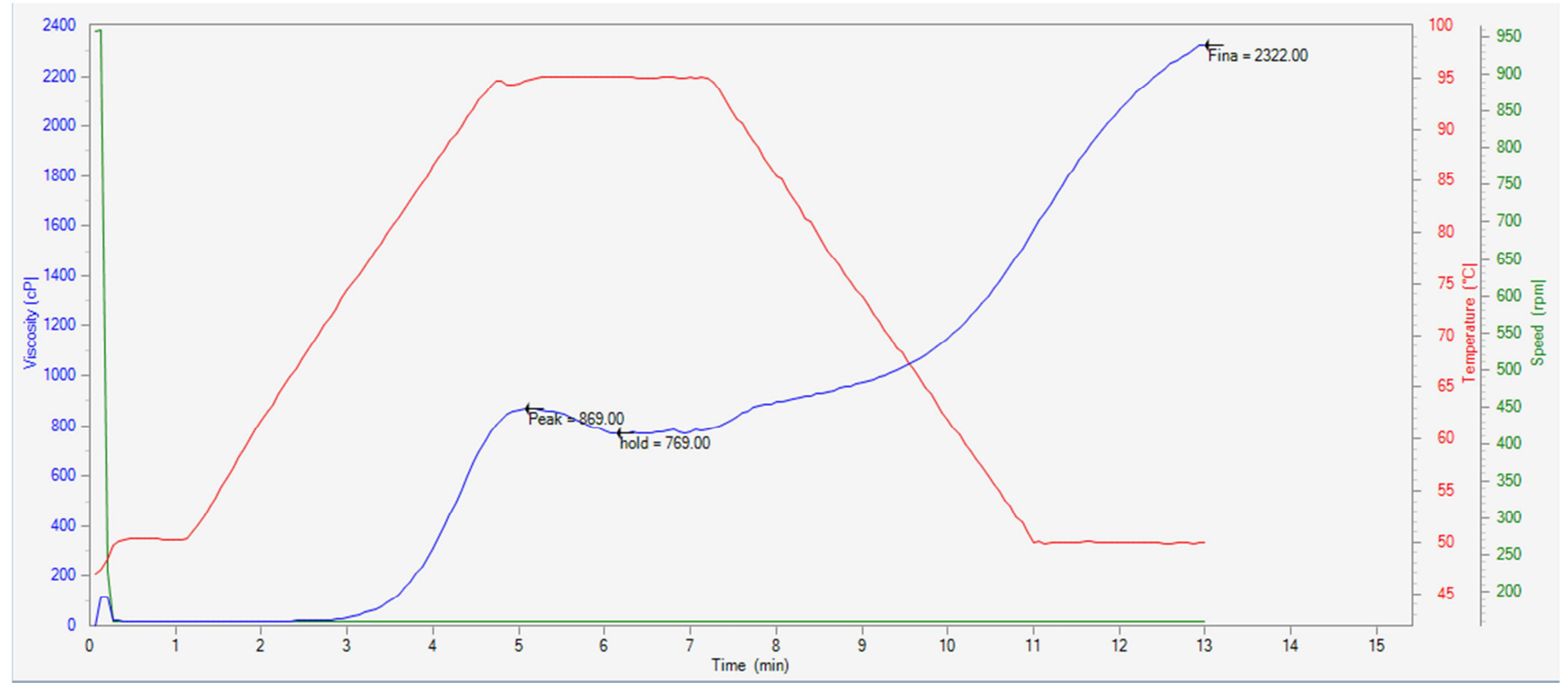

Figure 1. B1 (100\% Melkassa-1Q) pasting curve. 


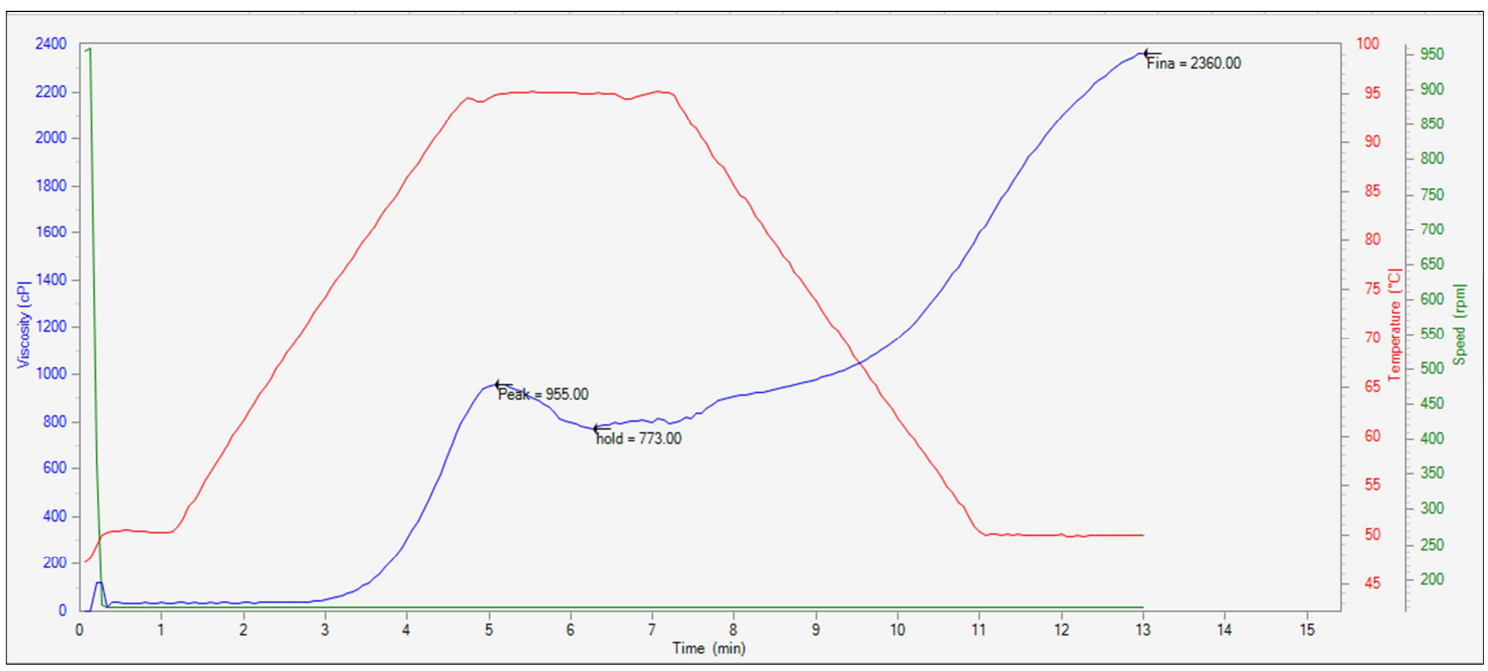

Figure 2. B2 (70\% Melkassa-1Q $+30 \%$ Teff) pasting curve,

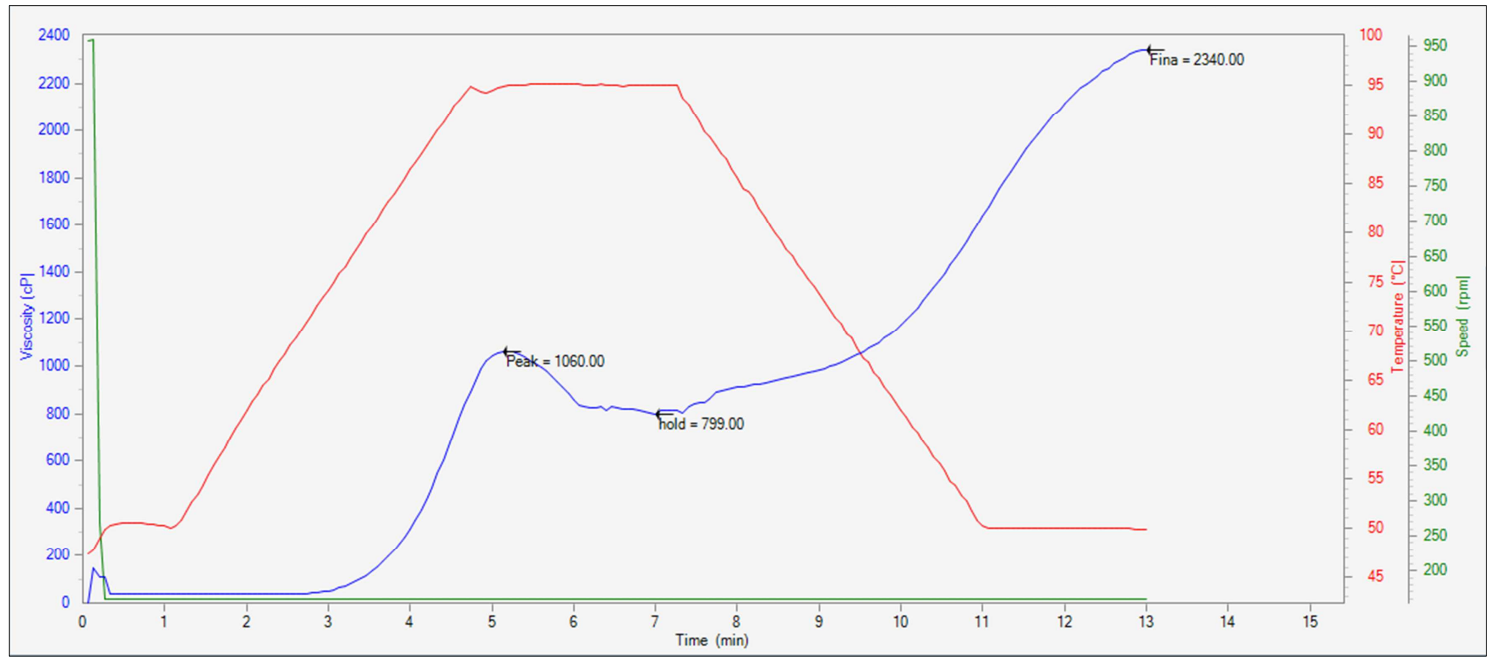

Figure 3. B3 (60\% Melkassa-1Q $+40 \%$ Teff) pasting curve.

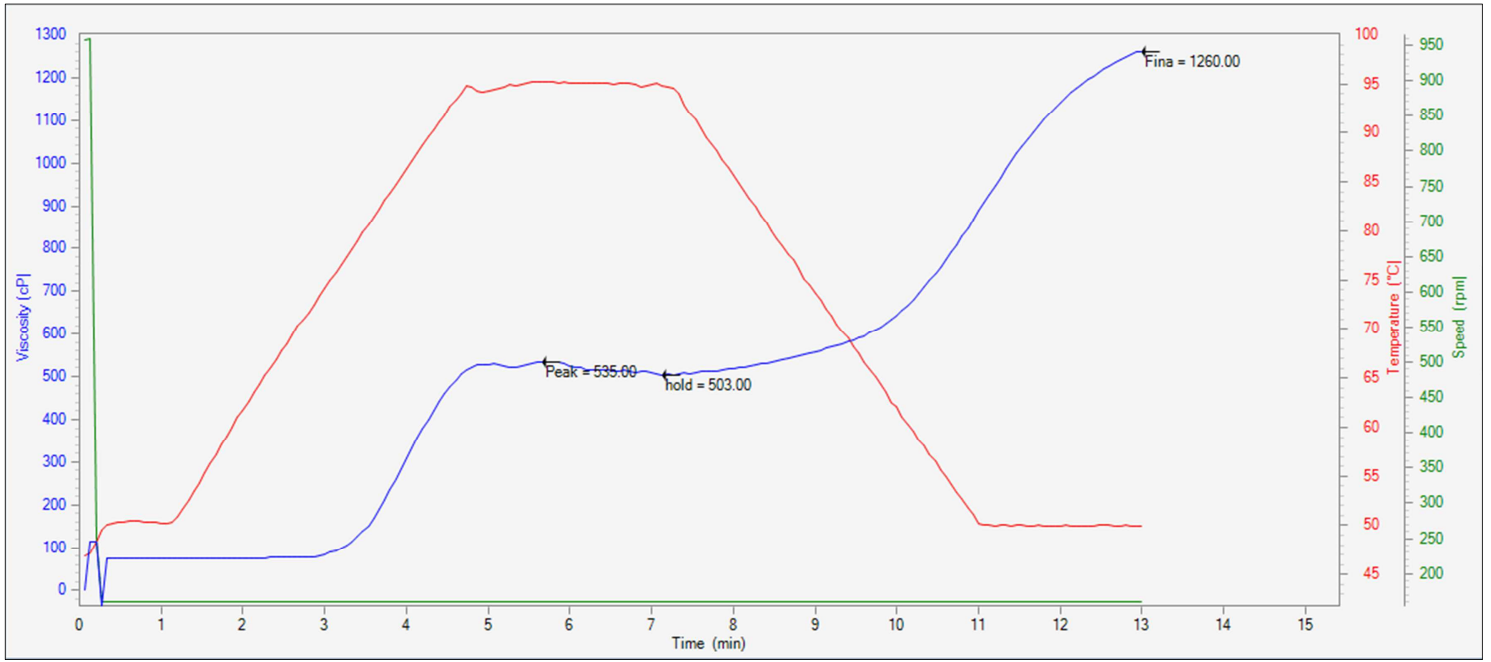

Figure 4. B4 (100\% Melkassa-6Q) pasting curve. 


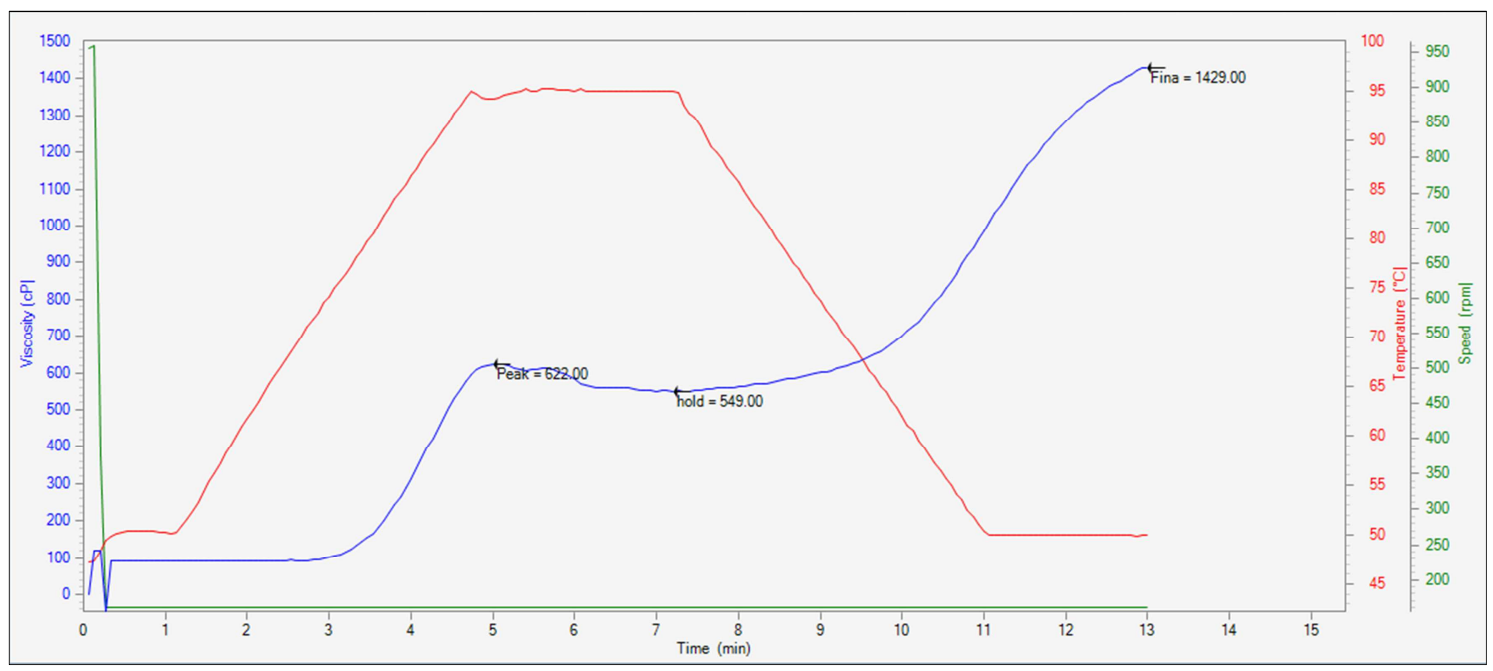

Figure 5. $B 5$ (70\% Melkassa-6Q $+30 \%$ Teff) pasting curve.

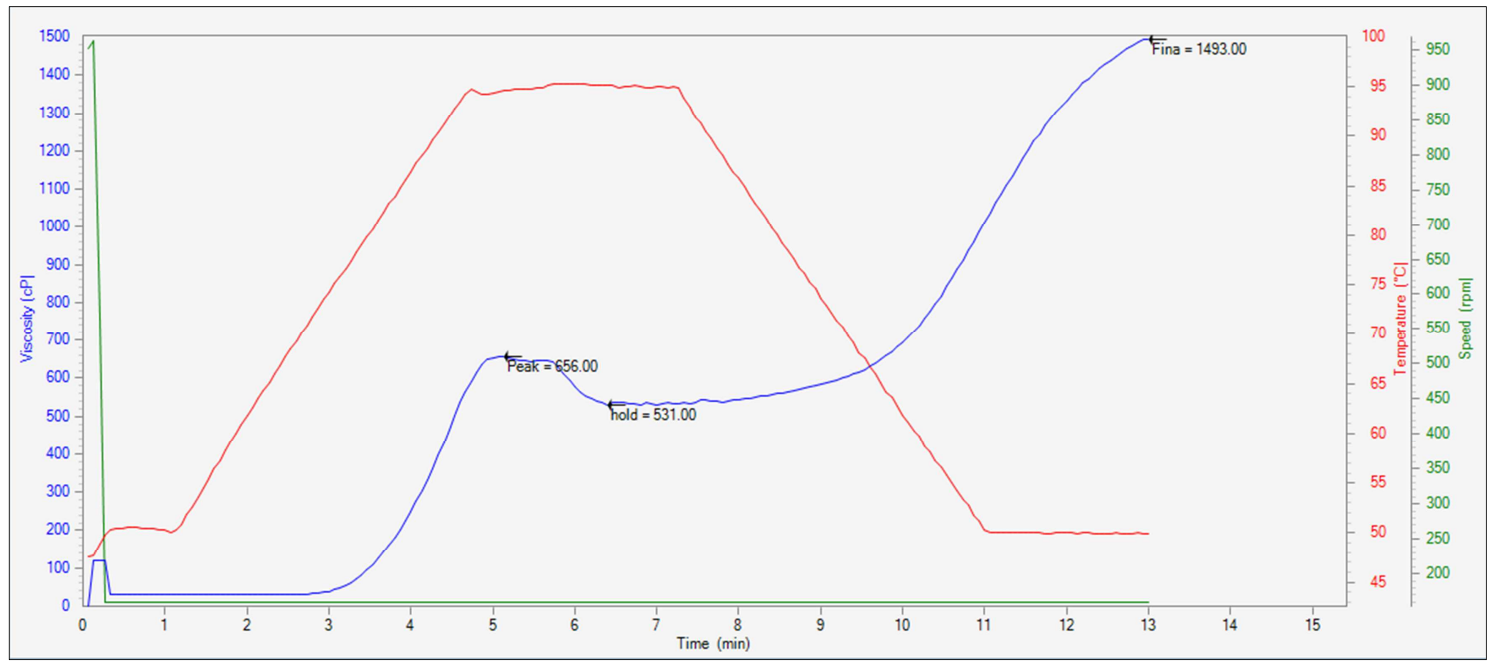

Figure 6. $B 6(60 \%$ Melkassa- $6 Q+40 \%$ Teff $)$ pasting curve.

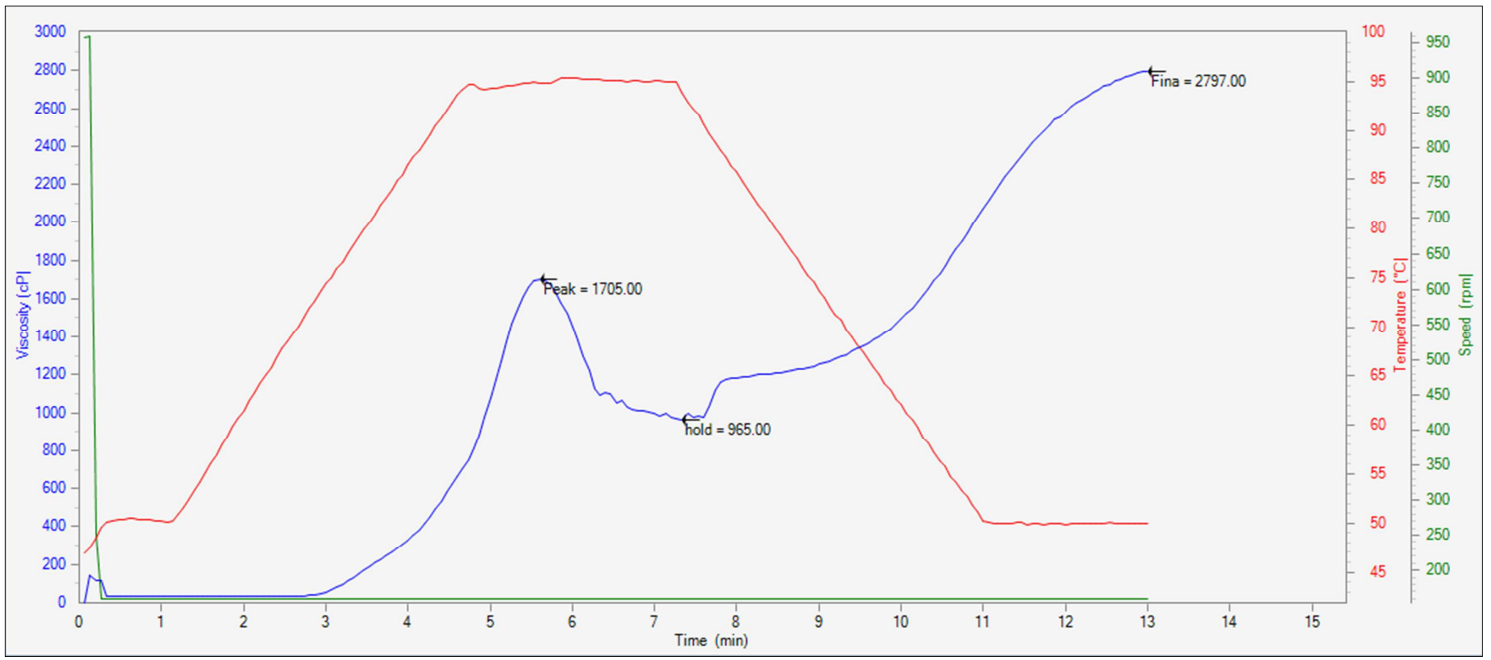

Figure 7. Teff pasting curve.

Final viscosity results ranged from 1232.00 to $2358.50 \mathrm{cP}$, and significant differences $(\mathrm{p}>0.05)$ were not found between 100:0, 70:30, and 60:40\% (Melkassa-1Q: teff) flour samples.
Similarly, significant differences $(\mathrm{p}>0.05)$ were not observed between 70:30 and 60:40 (Melkassa-6Q: teff) flour samples. The final viscosity gives an idea of the ability of a material to 
gel after cooking [17]. The difference between final viscosity and trough viscosity give rise to a pasting property known as setback viscosity. It is the phase of pasting curve after cooling the starches to $50^{\circ} \mathrm{C}$ [9]. Setback viscosity values varied from 740.50 to $1556.50 \mathrm{cP}$. Statistically, significant differences $(p>0.05)$ were not found between the composite flour samples of 70:30 and 60:40\% (Melkassa-1Q: teff), and Melkassa-1Q (100\%) flour. The lowest setback viscosity value was recorded for Melkassa-6Q (100\%) flour.

Peak time indicates the time at which the peak viscosity occurred in the pasting profile $[9,34]$. The pasting time of the flour samples varied from 5.04 to $5.70 \mathrm{mins}$, and the highest value was recorded for Melkassa-6Q (100\%) flour. The rest of the flour samples did not have statistically, significant difference $(p>0.05)$.

\section{Conclusions}

Quality protein maize and teff are important food crops in Ethiopia. Mixed flour from both crops are used to prepared injera, dabo, kitta, anebabero and porridge. Blending different flours in an appropriate ratio improves nutritional and product qualities. The current study showed that blending ratio and varieties had significant effect $(p<0.05)$ on the pasting properties of QPM-teff composite flours. Higher values of peak viscosity $(844.50 \mathrm{cP})$, trough viscosity $(749.50 \mathrm{cP})$, breakdown viscosity $(95.00 \mathrm{cP})$, final viscosity $(2204.50 \mathrm{cP})$, and setback viscosity $(1455.00 \mathrm{cP})$ were also recorded for Melkassa-1Q variety compared to Melkassa-6Q.

\section{Acknowledgements}

The author is thankful to Mr. Mulate Zerihun (Food Science Laboratory, Melkassa Agricultural Research Center) and Mr. Ayalew Alemu (Adigrat University, School of Chemical and Food Engineering) for their kind assistance during laboratory work.

\section{References}

[1] Adefris, T., Dagne, W., Abraham, T., Birhanu, T., Kassahun, B., Dennis, F., and Prasanna, B. M. (2015). Quality Protein Maize (QPM); A guide to the technology and its promotion in Ethiopia. CIMMYT: Addis Ababa, Ethiopia.

[2] Adegunwa, M. O., Ganiyu, A. A., Bakare, H. A., and Adebowale, A. A. (2014). Quality evaluation of composite millet chinchin. Agric. Biol. J. N. Am., 5 (1): 33-39.

[3] Adetuyi, F. O., Badejo, O. F., Ikujenlola, A. V., and Omosuli, S. V. (2009). Storage influence on the functional properties of malted and un-malted maize (Zea mays L.) and soybean (Glycine max) flour blends. Afr. J. Food Sci., 3 (2): 56-60.

[4] Ajanaku, K. O., Ajanaku, C. O., Edobor-Osoh, A., and Nwinyi, O. C. (2012). Nutritive value of sorghum ogi fortified with groundnut seed (Arachis hypogaea L.). Am. J. Food Technol., 7: 82-88.

[5] Barrera, G. N., Pérez, G. T., Ribotta, P. D., and Léon, A. E.
(2007). Influence of damaged starch on cookie and breadmaking quality. Eur. Food Res. Technol., 225: 1-7.

[6] Birara, E. (2017). Teff production and marketing in Ethiopia. Radix International Journal of Research in Social Science, 6: 117.

[7] Chomba, E., Westcott, C. M., Westcott, J. E., Mpabalwani, E. M., Krebs, N. F., Patinkin, Z. W., Palacios, N., and Hambidge, K. M. (2013). Zinc absorption from biofortified maize meets the requirements of young rural Zambian children. Journal of Nutrition, 145: 514-519.

[8] Deka, D., and Sit, N. (2016). Dual modification of taro starch by microwave and other heat moisture treatments. International Journal of Biological Macromolecules, 92: 416-422.

[9] Desalegn, A., and Hailu, D. (2020). Particle size distribution, rheological and pasting properties of wheat, anchote and their composite flour. Int. J. Food Nutri. Sci., 5 (2): 131-143.

[10] Kiin-Kabari, D. B., Eke-Ejiofor, J., and Giami, S. Y. (2015). Functional and pasting properties of wheat/plantain flours enriched with bambara groundnut protein concentrate. International Journal of Food Science and Nutrition Engineering, 5 (2): 75-81.

[11] Krivanek, A. F., De Groote, H., Gunaratna, N. S., Diallo, A. O., and Friesen, D. (2007). Breeding and disseminating quality protein maize (QPM) for Africa. Afr. J. Biotech., 6: 312-324.

[12] Machida, L., Derera, J., Tongoona, P., Langyintuo, A., and Macrobert. J. (2014). Exploration of farmers' preferences and perceptions of maize varieties: Implications on development and adoption of quality protein maize (QPM) varieties in Zimbabwe. Journal of Sustainable Development, 7: 194-207.

[13] Mbuya, K., Nkongolo, K. K., and Kalonji-Mbuyi, A. (2011). Nutritional analysis of quality protein maize varieties selected for agronomic characteristics in a breeding program. Int. J. Plant Breed. Genet., 5: 317-327.

[14] Mekonnen, M., Zarnkow, M., and Becker, T. (2014). Teff [Eragrostis teff (Zucc.) Trotter] as a raw material for malting, brewing and manufacturing of gluten-free foods and beverages: A review. J. Food Sci. Technol., 51 (11): 28812895.

[15] Nuss, E. T., and Tanumihardjo, S. A. (2011). Quality Protein Maize for Africa: Closing the protein inadequacy gap in vulnerable populations. Adv. Nutr., 2: 217-222.

[16] Ocheme, O. B., Adedeji, O. E., Chinma, C. E., Yakubu, C. M., and Ajibo, U. H. (2018). Proximate composition, functional, and pasting properties of wheat and groundnut protein concentrate flour blends. Food Sci. Nutr., 6: 1173-1178.

[17] Osungbaro, T. O., Jimoh, D., and Osundeyi, E. (2010). Functional and pasting properties of composite cassavasorghum flour meals. Agric. Biol. J. N. Am., 1 (4): 715-720.

[18] Ranskiv, V. S., Indira, V., and Chandhi, S. (2016). A study on quality protein maize (QPM) and genetic management for the nutritional protection of maize: Review. Glob. J. Anim. Breed. Genet., 4 (8): 295-304.

[19] Sagbo, F. S. Y., Aïssi, M. V., Hounkpatin, W. A., Houedo, C., Dansi, A., and Soumanou, M. M. (2017). Physicochemical and pasting properties of some local and improved maize varieties cultivated in Benin. Int. J. Biol. Chem. Sci., 11 (4): 17531765 . 
[20] Sangeeta, and Grewal, R. B. (2018). Pasting properties of maize flour from variety HQPM-1 and HQPM-7. Journal of Pharmacognosy and Phytochemistry, 7 (2): 223-225.

[21] Sanni, L. O., Ikuomola, D. P., and Sanni, S. A. (2001). Effect of length of fermentation and varieties on the qualities of sweet potato gari. Proceedings of the 8th Triennial Symposium of the International Society for Tropical Root Crops; 12 -16; Ibadan, Nigeria.

[22] Sofi, P. A., Wani, S. A., Rather, A. G., and Wani, S. H. (2009). Quality protein maize (QPM): Genetic manipulation for the nutritional fortification of maize. J. Plant Breed. Crop Sci., 1: 244-253.

[23] Tatham, A. S., Fido, R. J., Moore, C. M., Kasarda, D. D., Kuzmicky, D. D., Keen, J. N., and Shewry, P. R. (1996). Characterization of the major prolamins of teff (Eragrostis teff) and finger millet (Eleusine Coracana). Journal of Cereal Science, 24: 65-71.

[24] Teshome, A. (2017). The effect of the viscosity of ready to bake teff batter on the weight and other qualities of injera. Master's thesis: Addis Ababa University.

[25] Umer, A. (2019). Effect of blending ratio and natural fermentation time on the qualities of injera prepared from quality protein maize and teff flours. Master's thesis: Haramaya University.

[26] Workineh, A., and Ronda, F. (2014). Rheological and textural properties of teff [Eragrostis teff (Zucc.) Trotter] grain flour gels. Journal of Cereal Science, 60 (1): 122-130.

[27] E. Obeng-Bio, B. Badu-Apraku, B. E. Ifie, A. Danquah, E. T. Blay, B. Annor. (2019). Genetic analysis of grain yield and agronomic traits of early pro-vitamin A quality protein maize inbred lines in contrasting environments. The Journal of Agricultural Science 157, 413-433. https://doi.org/10.1017/S0021859619000753.
[28] Eke-Ejiofor, J., and Awajiogak, C. U. (2019). Effect of processing methods on the physicochemical, anti-nutrient and pasting properties of three commonly consumed soup thickeners in Nigeria. Asian Food Science Journal, 13 (4), 116. https://doi.org/10.9734/afsj/2019/v13i430115.

[29] Fan Zhu. (2019). Chemical composition and food uses of teff (Eragrostis tef). Food Chemistry, 15 (239): 402-415. doi: 10.1016/j.foodchem.2017.06.101.

[30] Gunaratna, N. S., De Groote, H., Nestel, P., Pixley, K. V., and Mccabe, G. P. (2010). A meta-analysis of community-based studies on quality protein maize. Food Policy, 35 (3): 202-210.

[31] J. O. Adepehin. (2020). Microbial diversity and pasting properties of finger millet (Eleusine coracana), pearl millet (Pennisetum glaucum) and sorghum (Sorghum bicolor) sourdoughs. Food Bioscience, 37: ISSN 2212-4292.

[32] Nkundabombi Marie Grace, Dororthy Nakimbugwe, and John H. Muyonga. (2016). Effect of processing methods on nutritional, sensory and physicochemical characteristics of biofortified bean flour. Food Science \& Nutrition, 4 (3): 384 397.

[33] Önder Yildiz, Bayram Yurt, Ayhan Baştürk, Ömer Said Toker, Mustafa Tahsin Yilmaz, Safa Karaman, Orhan Dağlioğlu. (2013). Pasting properties, texture profile and stressrelaxation behavior of wheat starch/dietary fiber systems, Food Research International, 53 (1): 278-290.

[34] Toibudeen, A. S., Omolola, H. G., Eunice, M. O., and Kudirat, T. A. (2020). Quality assessment of cookies made from composite flour of wheat, sorrel seed protein isolate and yellow cassava flours. Journal of Microbiology, Biotechnology and Food Sciences, 9: 6, doi: 10.15414/jmbfs.2020.9.6.1073-1079. 